\title{
The effect of new corporate accounting regime on earnings management: Evidence from Vietnam
}

\author{
Trang Cam Hoang \\ Faculty of Finance and Banking, Ton Duc Thang University, \\ Ho Chi Minh city, Vietnam \\ hoangcamtrang@tdtu.edu.vn

\section{Dempsey Michael Joseph ${ }^{1}$} \\ Financial Markets and Sustainability Research Group, Ton Duc \\ Thang University, Ho Chi Minh City, Viet Nam \\ Faculty of Finance and Banking, Ton Duc Thang University, \\ Ho Chi Minh city, Vietnam \\ dempsey@tdtu.edu.vn
}

\begin{abstract}
Following the mandatory adoption of new corporate accounting rules that bring Vietnamese accounting standards closer to the International Financial Reporting Standards (IFRS), this study examines the impact of these new rules on earnings management of Vietnamese listed firms. The study avails of financial statement figures during pre-adoption and post-adoption of the new corporate accounting regime (as of January 1, 2015) for the top-100 listed firms in Vietnam. The findings suggest there has been an improvement in earnings quality since listed firms moved to the new accounting regime.
\end{abstract}

Received:

December, 2018

1st Revision:

February, 2019

Accepted:

February, 2019

DOI:

$10.14254 / 2071$

$8330.2019 / 12-1 / 6$

Keywords: new corporate accounting regime adoption, earnings management, Vietnam.

JEL Classification: M41, M48.

\section{INTRODUCTION}

As of January 1, 2015, Vietnamese government formalized its decision to adopt a new corporate accounting regime. This new regime brings Vietnamese accounting standards closer to the International Financial Reporting Standards (IFRS). Consequently, it may be expected that the capital market

\footnotetext{
${ }^{1}$ Corresponding author. Financial Markets and Sustainability Research Group, Faculty of Finance and Banking, Ton Duc Thang University, 19 Nguyen Huu Tho St, Tan Phong Ward, District 7, Ho Chi Minh City, Vietnam. E-mail: dempsey@,tdtu.edu.vn
} 
participants will wish to understand how accounting quality has been affected by this transition (Chua et al., 2012). To address this question, the study examines the impact of the new corporate accounting regime on financial reporting in the context of Vietnamese capital market. Specifically, earnings management is compared as before and after the mandatory introduction of the new regime.

Twenty six Vietnamese Accounting Standards (VAS) were issued by the Ministry of Finance (MOF) during the period 2001 to 2005 aimed at achieving greater uniformity with the International Accounting Standards (IAS) and IFRS as they existed at that time. However, not all IAS/IFRS standards were adopted in Vietnam, and no significant changes have been made to the VASs since their issuance (Huynh et al., 2012). The MOF of Vietnam also issues circulars that interpret the requirements of Vietnamese corporate accounting system and the VAS. This guidance includes detailed bookkeeping and journal entries for various type of transactions related to a subject. The most recent Circular No. 200/2014/TT stipulates an amended Vietnamese accounting system for firms, and introduces a number of changes aimed at bringing the VASs closer to the IFRSs (Bach \& Hang, 2016).

Basing on the sample of 348 firm-year observations for the top-100 Vietnamese listed firms, we have found that mandatory adoption of the new corporate accounting regime has led to significant improvements in earnings quality. Specifically, the study finds evidence that following this adoption, Vietnamese listed firms engage in significantly less earnings management by way of income smoothing as well as less management towards a positive target. The findings are expected to be relevant for the Ministry of Finance of Vietnam and other standard setters, as well as policy-makers, regulators, researchers, and other stakeholders.

The remainder of the paper is organized as follows. The following section develops the hypotheses and Section 3 explains the data and research design. Section 4 presents the results. Section 5 offers a summary and concluding remarks.

\section{HYPOTHESES DEVELOPMENT}

Evidence for the impact of the new accounting regime on earnings management (smoothing) by firms appears to be mixed. In a study comparing firms from 20 countries that have adopted IFRS (mostly of the European Union) with those from non-adopting countries, Ahmed et al. (2013) find that IFRS adoption has led to significant increases in income smoothing and aggressive reporting of accruals in countries of strong enforcement, but little impact in countries of weak enforcement. Callao and Jarne (2010) also find that earnings management has intensified since the adoption of IFRS in Europe, as discretionary accruals increased in the period following implementation. However, Doukakis (2014) finds that mandatory IFRS adoption has had no signifcant impact on either real or accrual-based earnings management practices in 22 European countries. The evidence is also the other way. In a sample of 15 European countries, Chen et al. (2010) demonstrate that a majority of accounting quality measures, including those based on accrual characteristics commonly adopted in the literature, show improvement after mandatory IFRS adoption in 2005.

Countries in other areas have also contributed to the debate. For example, Pelucio-Grecco, Geron, Grecco and Lima (2014) evaluate whether changes in accounting practices brought a reduction in earnings management in listed Brazilian non-financial companies through discretionary accruals and find that the regulatory environment contributes to the extent that IFRS has had a restrictive effect on earnings management. Recognizing that the purpose of the new reporting standards is to make the financial statements of companies more transparent and comparable, Baig and AliKhan (2016) investigate their impact on the earnings management of public limited companies in Pakistan and also conclude that, notwithstanding mixed evidence, there has been an overall decreasing trend in the use of earnings 
management since 2001. For Russian firms, however, Malofeeva (2018) finds that earnings management has intensified following adoption of IFRS.

Interestingly, findings also suggest that in periods of voluntary adoption of IFRS, the impact of adoption has been that of improved accounting quality (Ashbaugh \& Pincus, 2001; Barth et al., 2008); while in periods when the IFRS became mandatory, a good deal of evidence has suggested either a negative or no outcome on accounting quality, particularly, in Europe and Australia; for example, Paananen and Lin (2009) for German firms, Jeanjean and Stolowy (2008) for Australian, UK and French firms; and Christensen et al. (2008), while finding a positive effect in the period of voluntary adoption in Germany, find no effect following mandatory adoption. Nevertheless, the evidence is not always one way: Chua et al. (2012) finds that mandatory adoption of IFRS has generally improved accounting quality in regard to smoothing for Australia.

One suggestion has been that self-selection during voluntary periods of adoption has allowed firms to choose the disclosure rules that best reveal prospects of the firm as well as any misuse of funds by managers, thereby reducing information asymmetry between the firm and its shareholders. In contrast, for mandatory adoption, it may be that the findings are dominated by a more cynical adoption of the standards. In this context, Capkun, Collins and Jeanjean (2016) consider that the early voluntary adopters had incentives to increase the transparency of their reporting in order to attract outside capital, while those firms that waited until IFRS adoption became mandatory in EU countries lacked incentives for transparent reporting leading to increases in earnings management (smoothing) after IFRS adoption. Nevertheless, they maintain that the IFRS standards that went into effect in 2005 provided greater flexibility of accounting choices because of vague criteria, and that this greater flexibility coupled with the lack of clear guidance on how to implement these new standards actually led to greater earnings management as smoothing. Consistent with this view, they find increases in earnings management from pre-2005 to post-2005 for firms in countries that allowed early IAS/IFRS adoption, as well as for firms in countries that did not allow early IFRS adoption.

It is therefore not immediately clear as to how we might anticipate the impact of the new corporate accounting regime adoption on accounting quality in Vietnam. However, both legal enforcement and investor protection are strong in Vietnam. This leads us to advance the paper's essential hypothesis:

Earnings management in Vietnamese listed firms is lower in the new corporate accounting regime adoption period than in the pre-adoption period.

\section{METHODOLOGY}

\subsection{Sample}

The sample consists of the top-100 listed Vietnamese firms covering the period from December 2012 to December 2013 as the pre-adoption period, and from December 2015 to December 2016 as the adoption period. The study excludes 2014 to avoid transition effects in the year prior to adoption (Wali \& Boujelbene, 2017). Firms for which the data are missing or which are considered unrealible are eliminated. The final sample consists of 348 observations.

\subsection{Earnings management measure}

The literature widely uses two types of earnings management measures: accounting-based measures and market-based measures. An assumption underlying the use of market-based measures is that markets 
are able to efficiently interpret accounting information in making decisions about firms. Recognizing that the Vietnamese market is new and semi-efficient, this paper chooses to focus on accounting-based measures (Phan \& Zhou, 2014; Truong et al., 2008). Additionally, accounting-based measures more directly reflect earnings quality when it can be determined that they are being manipulated by management, whereas market-based measures are harder to manipulate (Prior et al., 2008). On this basis, the methodolgy is that of empirical deductions from the data, with which to either support or refure the paper's hypotheses, as follows.

We consider two perspectives of earnings management: (1) earnings smoothing and (2) management of earnings towards a positive target. We develop three constucts to proxy for earnings smoothing and one to proxy for management of earnings towards a target. This is achieved by closely following the metrics used in Chua et al. (2012) and Barth et al. (2008).

The first proxy for earnings smoothing seeks to capture the variability of the change in net income scaled by total assets $(\Delta \mathrm{NI})$ that can be attributed to the prevailing accounting regime. For this purpose, we commence with the regression:

$$
\Delta N I_{i}=\alpha_{0}+\sum \gamma_{i, j} \text { control variables }_{j}+\operatorname{Error}_{(\Delta N I) i}
$$

with control variables:

TURN = sales divided by total assets;

$\mathrm{LEV}=$ total liabilities divided by equity book value;

DISSUE $=$ percentage change in total liabilities;

GROWTH $=$ percentage change in sales;

$\mathrm{CFO}=$ annual net cash flow from operating activities divided by total assets;

EISSUE $=$ percentage change in common stock;

SIZE = natural logarithm of total assets as of the end of the year;

BIG4 = dummy variable that equals 1 if the firm's auditor is one of the four large internationalaccounting firms, and 0 otherwise;

for which the intercept $\alpha_{0}$ in combination with the error term Error $_{(\Delta N I) i}$ is interpreted as capturing the residual component of $\Delta \mathrm{NI}$ that remains unaccounted for (by conventional control variables), which we designate as $\Delta \mathrm{NI}^{\#}$. We then consider that the variability of $\Delta \mathrm{NI}^{\#}$ as:

$$
\text { Variability of } \Delta \mathrm{NI}^{\#}=\sigma^{2} \operatorname{Error}(\Delta \mathrm{N}) i
$$

provides a measure of earnings smoothing, since, to the extent that earnings are being smoothed, we expect a lower value for the Variability of $\Delta \mathrm{NI}^{\#}$ term.

The above regression is run separately for the pre-adoption and the post-adoption periods using the firm-year observations that have been pooled into the respective time periods. The variance of the residuals for each respective group are compared using a variance ratio F-test.

When firms experience more volatilie cash flows, they can expect more volatile net income. However, if firms use accruals to manage earnings, the variability of the change in net income should be lower than that of operating cash flows. The second earnings smoothing metric therefore considers the mean ratio of the variability of the change in net income $(\Delta \mathrm{NI})$ to the variability of the change in operating cash flows $(\Delta \mathrm{CF})$ as 


$$
\frac{\text { Variability of } \Delta \mathrm{NI}^{\#}}{\text { Variability of } \Delta \mathrm{CF}^{\#}}=\frac{\sigma_{E \operatorname{Error}(\Delta N I) i}^{2}}{\sigma_{E \operatorname{rror}(\Delta C F) i}^{2}}
$$

where $\Delta \mathrm{CF} \#$ is defined in alalogy with $\Delta \mathrm{NI}^{\#}$. Thus, in analogy with Equation 1, we form the regression:

$$
\Delta C F_{i}=\alpha_{0}+\sum \gamma_{i, j} \text { control variables }{ }_{j}+\text { Error }_{(\triangle C F) i}
$$

so that the intercept $\left(\alpha_{0}\right)$ in combination with the error term $\operatorname{Error}_{(\triangle C F) i}$ may again be interpreted as capturing the residual component, which we designate similarly as $\triangle \mathrm{CF}^{\#}$, with the variability of $\Delta \mathrm{CF}^{\#}$ determined as:

$$
\text { Variability of } \Delta \mathrm{CF}^{\#}=\sigma^{2} \operatorname{Eror}(\Delta C \mathrm{CF}) i
$$

Following Chua et al. (2012), we test whether the ratio of the variances has changed significantly across the pre-and post-adoption periods using a variance ratio F-test.

Our third earnings smoothing metric is based on the Spearman correlation between accruals and cash flows. We argue that, although we anticipate a negative correlation between accruals (ACC) and cash flows (CF), a larger magnitude of negative correlaton between these two variables is indicaive of eanings smoothing. To this end, in analogy with equation (1), we determine the residuals from the equations:

$$
\begin{aligned}
& C_{i}=\alpha_{0}+\sum \gamma_{i, j} \text { control variables }_{j}+\text { Error }_{(C F) i} \\
& \text { ACC }_{i}=\alpha_{0}+\sum \gamma_{i, j} \text { control variables }_{j}+\text { Error }_{(A C C) i}
\end{aligned}
$$

where $\mathrm{ACC}_{\mathrm{i}}=\mathrm{NI}_{\mathrm{i}}-\mathrm{CF}_{\mathrm{i}}$, and then determine the Spearman correlation between the cash flows $\mathrm{CF}^{\#}$ and accruals ACC ${ }^{\#}$ as

$$
\operatorname{CORR}\left(\operatorname{Error}_{(\mathrm{CF}) \mathrm{i}}, \operatorname{Error}_{(\mathrm{ACC}) i}\right)
$$

As with the matrics from equations (2) and (3), we compare the correlations of residuals from equations (6) and (7) as equation (8) separeately for the pre-adoption and the post-adoption periods.

To examine the prevalence of management of earnings toward a positive target, we again pool observations separately for the pre-adoption and post-adoption periods so that the difference in frequency of small positive earnings (SPOS) across periods can be determined. We consider that a significant decrease in the management of small positive amounts in the post-adoption period indicates a move to higher accounting quality in the adoption period.

Following prior research (Barth et al., 2008; Chua et al., 2012), we apply a dummy variable for small positive earnings (SPOS) that is set equal to 1 for observations for which annual net income (scaled by total assets) is between 0 and 0.01 , and is set equal to 0 otherwise. The binary variable SPOS is the dependent variable, with POST, which identifies the regime as either pre- $(\mathrm{POST}=0)$ or post- $(\mathrm{POST}=$ 1) transition, as the independent variable. Allowing control variables to capture effects exogneous to the change in accounting regime (as in prior studies), we formulae the regression equation with which to test the paper's hypothesis as 


$$
\operatorname{SPOS}_{i}=\alpha_{0}+\alpha_{1} \text { POST }+\sum \gamma_{i, j} \text { control variables }_{j}+\text { Error }_{i}
$$

A significant negative coefficient $\alpha 1$ on POST would imply that firms managed earnings toward small positive amounts more frequently in the pre-adoption period than in the adoption period, indicating a move to higher accounting quality in the adoption period.

\section{RESULTS}

\subsection{Descriptive Statistics}

Table 1 presents the descriptive statistics for the test variables and control variables across the preadoption and the post-adoption periods. Among the test variables we observe statistically significant differences between the pre-adoption and the post-adoption periods for the change in operating cash flow $(\triangle \mathrm{CF})$, accruals (ACC), operating cash flow (CF), and small positive net income (SPOS). In addition, the mean value of the small positive net income variable SPOS is reduced in the post-adoption period (from 0.1379 to 0.0575$)$. Thus the table provides some indication that firms are less likely to manage earnings towards a positive target in the post-adoption period.

The descriptive statistics on the control variables indicate that on average firms in the post-adoption period are somewhat larger (SIZE) and more likely to be audited by a Big 4 (BIG 4) (possibly to overcome the reporting complexity faced during the transition to new new corporate accounting rules), and that in the post-adoption period, they have issued more equity (EISSUE) and debt securities (DISSUE). The findings are consistent with those of prior research (Barth et al., 2008; Christensen et al., 2015).

Table 1

Descriptive Statistics for Variables Used in Analyses

\begin{tabular}{|l|c|c|c|c|c|c|}
\hline & \multicolumn{3}{|c|}{ Pre (n = 174) } & \multicolumn{3}{c|}{ Post (n = 174) } \\
\hline & Mean & Median & Std.dev. & Mean & Median & Std.dev. \\
\hline Test variables & & & & & & \\
\hline$\Delta$ NI & 0.0102 & 0.0041 & 0.0556 & 0.0111 & 0.0056 & 0.0886 \\
\hline$\Delta$ CF & 0.0349 & 0.0273 & 0.1712 & $0.0072^{*}$ & 0.0166 & 0.1650 \\
\hline ACC & -0.0008 & 0.0005 & 0.1120 & $0.0360^{* * *}$ & 0.0053 & 0.1436 \\
\hline CF & 0.0953 & 0.0762 & 0.1432 & $0.0712^{*}$ & 0.0687 & 0.1466 \\
\hline SPOS & 0.1379 & 0.0000 & 0.3458 & $0.0575^{* *}$ & $0.0000^{* *}$ & 0.2334 \\
\hline Control variables & & & & & & 0.0687 \\
\hline CF & 0.0953 & 0.0762 & 0.1432 & $0.0712^{*}$ & 0.1466 \\
\hline BIG4 & 0.5115 & 1.0000 & 0.5013 & $0.6207 * *$ & 1.0000 & 0.4866 \\
\hline TURN & 1.0189 & 0.7604 & 0.9477 & 0.9549 & 0.6846 & 0.8314 \\
\hline LEV & 0.4611 & 0.4724 & 0.1883 & 0.4453 & 0.4587 & 0.1982 \\
\hline GROWTH & 0.2345 & 0.1037 & 0.8632 & 0.2206 & 0.0769 & 0.5256 \\
\hline EISSUE & 0.1323 & 0.0845 & 0.1694 & 0.1755 & 0.1085 & 0.2475 \\
\hline DISSUE & 0.1497 & 0.0878 & 0.3742 & 0.2110 & 0.0993 & 0.4878 \\
\hline SIZE & 12.4227 & 12.4275 & 0.5242 & $12.6299^{* * *}$ & $12.5612^{* * *}$ & 0.4978 \\
\hline
\end{tabular}

*, **, *** Represent significant difference between the pre-adoption and the post-adoption periods at the 10\%, 5\%, and 1\% levels, respectively (two-tailed).

Definition of variables: 
$\Delta N I$ is the change in net income, scaled by end-of-year total assets; $\triangle C F$ is the change in annual cash flow from operations, scaled by end of-year total assets; ACC is the earnings less cash flow from operations, scaled by end-of-year total assets; CF is annual net cash flow from operating activities, scaled by end-of-year total assets; SPOS is an indicator variable that equals one if net income scaled by total assets is between 0 and 0.01; BIG4 is an indicator variable that equals one if the firm's auditor is is one of the four large international accounting firms, and zero otherwise; TURN is sales divided by end-of-year total assets; LEV is end of year total liabilities divided by end of year total equity book value; GROWTH is percentage change in sales; EISSUE is percentage change in common stock; DISSUE is percentage change in total liabilities; CFO is annual net cash flow from operating activities divided by total assets; SIZE is the natural logarithm of end-of-year total assets.

Table 2 reports the correlation matrix for the test and control variables used in the study. Overall, the correlations between the variables are modest, which suggests a low level of multicollinearity. The only exception is the correlation between accruals (ACC) and cash flows (CF), which are highly negatively correlated in both pre-adoption (Panel A) and post-adoption periods (Panel B) (- 0.75, significant at 1 percent significance for both periods). This is consistent with the prior expectation that a negative correlation reflects the natural outcome of accrual accounting (Barth et al., 2008; Chua et al., 2012). There is a statistically significant positive association between $\Delta \mathrm{CF}$ and $\Delta \mathrm{NI}$ in the pre-adoption $(0.22$, at 1 percent significance) with a negative association in the post-adoption (-0.15, at 5 percent significance).

Correlation Matrix

Panel A: Correlation Matrix between variables of earnings smoothing for pre-adoption period

\begin{tabular}{|c|c|c|c|c|c|c|c|c|c|c|c|}
\hline & $\Delta \mathrm{NI}$ & $\Delta \mathrm{CF}$ & ACC & CF & BIG4 & $\begin{array}{c}\text { TUR } \\
\mathbf{N}\end{array}$ & LEV & $\begin{array}{c}\text { GRO } \\
\text { WTH }\end{array}$ & $\begin{array}{c}\text { EISS } \\
\text { UE }\end{array}$ & $\begin{array}{c}\text { DISS } \\
\text { UE }\end{array}$ & SIZE \\
\hline$\Delta \mathbf{N I}$ & 1.0000 & & & & & & & & & & \\
\hline \multirow[t]{2}{*}{$\Delta \mathrm{CF}$} & $0.2163^{*}$ & 1.0000 & & & & & & & & & \\
\hline & 0.0041 & & & & & & & & & & \\
\hline \multirow{2}{*}{ ACC } & -0.0334 & $-0.6557^{*}$ & 1.0000 & & & & & & & & \\
\hline & 0.6616 & 0.0000 & & & & & & & & & \\
\hline \multirow[t]{2}{*}{$\mathrm{CF}$} & $0.2913^{*}$ & $0.5719^{*}$ & $-0.7543^{*}$ & 1.0000 & & & & & & & \\
\hline & 0.0001 & 0.0000 & 0.0000 & & & & & & & & \\
\hline \multirow{2}{*}{ BIG4 } & $-0.1685^{*}$ & -0.0569 & 0.0279 & -0.1044 & 1.0000 & & & & & & \\
\hline & 0.0262 & 0.4557 & 0.7151 & 0.1703 & & & & & & & \\
\hline \multirow[t]{2}{*}{$\begin{array}{c}\text { TUR } \\
\mathbf{N}\end{array}$} & 0.0823 & 0.1245 & $-0.1771^{*}$ & $0.3512^{*}$ & -0.0429 & 1.0000 & & & & & \\
\hline & 0.2801 & 0.1016 & 0.0194 & 0.0000 & 0.5736 & & & & & & \\
\hline \multirow[t]{2}{*}{ LEV } & $-0.1590^{*}$ & -0.0380 & 0.0067 & $-0.4046^{*}$ & $0.1796 *$ & 0.0413 & 1.0000 & & & & \\
\hline & 0.0362 & 0.6185 & 0.9302 & 0.0000 & 0.0177 & 0.5884 & & & & & \\
\hline \multirow[t]{2}{*}{$\begin{array}{c}\text { GRO } \\
\text { WTH } \\
\end{array}$} & $0.1305^{*}$ & 0.1023 & -0.0999 & 0.0436 & 0.0436 & 0.0398 & $0.1766^{*}$ & 1.0000 & & & \\
\hline & 0.0861 & 0.1792 & 0.1895 & 0.5678 & 0.5680 & 0.6022 & 0.0197 & & & & \\
\hline \multirow[t]{2}{*}{$\begin{array}{c}\text { EISS } \\
\text { UE }\end{array}$} & 0.3084* & $0.1554^{*}$ & -0.0784 & $0.2849 *$ & -0.0711 & $0.2409 *$ & -0.0033 & $0.1382^{*}$ & 1.0000 & & \\
\hline & 0.0000 & 0.0406 & 0.3037 & 0.0001 & 0.3514 & 0.0014 & 0.9652 & 0.0690 & & & \\
\hline \multirow[t]{2}{*}{$\begin{array}{c}\text { DISS } \\
\text { UE }\end{array}$} & 0.0303 & $0.1277^{*}$ & -0.0777 & $0.2156^{*}$ & 0.0306 & $0.2672^{*}$ & 0.0176 & $0.1837^{*}$ & $0.1995^{*}$ & 1.0000 & \\
\hline & 0.6917 & 0.0930 & 0.3084 & 0.0043 & 0.6883 & 0.0004 & 0.8177 & 0.0152 & 0.0083 & & \\
\hline \multirow[t]{2}{*}{ SIZE } & $-0.1284 *$ & -0.1125 & $0.1658^{*}$ & $-0.3261 *$ & $0.4500^{*}$ & $-0.3115^{*}$ & $0.4214^{*}$ & 0.1219 & -0.0127 & 0.0600 & 1.0000 \\
\hline & 0.0914 & 0.1394 & 0.0288 & 0.0000 & 0.0000 & 0.0000 & 0.0000 & 0.1090 & 0.8678 & 0.4315 & \\
\hline
\end{tabular}

$*$ represents the level of significance $<=10 \%$ in two-tailed tests. 
Panel B: Correlation Matrix between variables of earnings smoothing for post-adoption period

\begin{tabular}{|l|c|c|c|c|c|c|c|c|c|c|c|}
\hline & $\Delta \mathbf{N I}$ & $\Delta \mathbf{C F}$ & $\mathbf{A C C}$ & $\mathbf{C F}$ & $\mathbf{B I G} 4$ & $\begin{array}{c}\text { TUR } \\
\mathbf{N}\end{array}$ & $\mathbf{L E V}$ & $\begin{array}{c}\text { GRO } \\
\text { WTH }\end{array}$ & $\begin{array}{c}\text { EISS } \\
\text { UE }\end{array}$ & $\begin{array}{c}\text { DISS } \\
\text { UE }\end{array}$ & SIZE \\
\hline$\Delta$ NI & 1.0000 & & & & & & & & & & \\
\hline$\Delta$ CF & $-0.1503^{*}$ & 1.0000 & & & & & & & & & \\
\hline & 0.0478 & & & & & & & & & & \\
\hline ACC & $0.3260^{*}$ & $-0.7203^{*}$ & 1.0000 & & & & & & & & \\
\hline & 0.0000 & 0.0000 & & & & & & & & & \\
\hline CF & 0.0313 & $0.6033^{*}$ & $-0.7468^{*}$ & 1.0000 & & & & & & & \\
\hline & 0.6815 & 0.0000 & 0.0000 & & & & & & & & \\
\hline BIG4 & -0.0380 & 0.0141 & -0.1069 & 0.0095 & 1.0000 & & & & & & \\
\hline & 0.6182 & 0.8534 & 0.1602 & 0.9010 & & & & & & & \\
\hline $\begin{array}{l}\text { TUR } \\
\text { N }\end{array}$ & $0.2595^{*}$ & $-0.1410^{*}$ & $0.2086^{*}$ & 0.0939 & -0.0865 & 1.0000 & & & & & \\
\hline & 0.0005 & 0.0635 & 0.0057 & 0.2180 & 0.2562 & & & & & & \\
\hline LEV & -0.0511 & 0.0078 & -0.0104 & $-0.2752^{*}$ & $0.1737 *$ & $0.1325^{*}$ & 1.0000 & & & & \\
\hline & 0.5029 & 0.9186 & 0.8920 & 0.0002 & 0.0219 & 0.0813 & & & & & \\
\hline $\begin{array}{l}\text { GRO } \\
\text { WTH }\end{array}$ & $0.3005^{*}$ & $-0.1391^{*}$ & $0.2672^{*}$ & $-0.2064^{*}$ & -0.0651 & 0.0820 & 0.0729 & 1.0000 & & & \\
\hline & 0.0001 & 0.0671 & 0.0004 & 0.0063 & 0.3931 & 0.2818 & 0.3393 & & & & \\
\hline $\begin{array}{l}\text { EISS } \\
\text { UE }\end{array}$ & $0.3232^{*}$ & $-0.2565^{*}$ & $0.4476^{*}$ & $-0.2722^{*}$ & -0.0772 & $0.2200^{*}$ & 0.0166 & $0.4589^{*}$ & 1.0000 & & \\
\hline & 0.0000 & 0.0006 & 0.0000 & 0.0003 & 0.3112 & 0.0035 & 0.8278 & 0.0000 & & & \\
\hline $\begin{array}{l}\text { DISS } \\
\text { UE }\end{array}$ & 0.1048 & 0.0109 & $0.1872^{*}$ & -0.1186 & 0.0656 & 0.1179 & $0.2750^{*}$ & $0.2345^{*}$ & $0.3698^{*}$ & 1.0000 & \\
\hline & 0.1689 & 0.8863 & 0.0134 & 0.1192 & 0.3895 & 0.1212 & 0.0002 & 0.0018 & 0.0000 & & \\
\hline SIZE & -0.0129 & 0.0439 & -0.0415 & $-0.1836^{*}$ & $0.3485^{*}$ & $-0.2512^{*}$ & $0.4502^{*}$ & $0.1533^{*}$ & 0.1234 & $0.2128^{*}$ & 1.0000 \\
\hline & 0.8654 & 0.5653 & 0.5871 & 0.0153 & 0.0000 & 0.0008 & 0.0000 & 0.0434 & 0.1049 & 0.0048 & \\
\hline
\end{tabular}

$*$ represents the level of significance $<=10 \%$ in two-tailed tests.

Panel $\mathrm{C}$ reveals a statistically significant negative association between managing earnings toward targets (SPOS) and POST (-0.14, at 5 percent sigificance), suggesting that firms engage in managing earnings toward targets less during the adoption period. The panel reveals that firms with higher asset turnover rates (TURN), more cash flow (CF), more equity (EISSUE) and debt securities (DISSUE) engage in managing earnings toward targets less frequently, while firms with larger sizes (SIZE) and higher financial leverage (LEV) engage in managing earnings toward targets more frequently. 
Panel C: Correlation Matrix between variables of managing earnings toward a positive target for both pre- and post-adoption periods

\begin{tabular}{|l|c|c|c|c|c|c|c|c|c|c|}
\hline & SPOS & POST & CF & BIG4 & TURN & LEV & $\begin{array}{c}\text { GROW } \\
\text { TH }\end{array}$ & $\begin{array}{c}\text { EISSU } \\
\text { E }\end{array}$ & $\begin{array}{c}\text { DISSU } \\
\text { E }\end{array}$ & SIZE \\
\hline & & & & & & & & & & \\
\hline SPOS & 1.0000 & & & & & & & & & \\
\hline POST & $-0.1355^{*}$ & 1.0000 & & & & & & & & \\
\hline & 0.0114 & & & & & & & & & \\
\hline CF & $-0.1551^{*}$ & -0.0829 & 1.0000 & & & & & & & \\
\hline & 0.0037 & 0.1226 & & & & & & & & \\
\hline BIG4 & 0.0147 & $0.1102^{*}$ & -0.0563 & 1.0000 & & & & & & \\
\hline & 0.7846 & 0.0400 & 0.2949 & & & & & & & \\
\hline TURN & $-0.2559^{*}$ & -0.0359 & $0.2308^{*}$ & -0.0665 & 1.0000 & & & & & \\
\hline & 0.0000 & 0.5039 & 0.0000 & 0.2163 & & & & & & \\
\hline LEV & $0.1532^{*}$ & -0.0409 & $-0.3326^{*}$ & $0.1707^{*}$ & 0.0861 & 1.0000 & & & & \\
\hline & 0.0042 & 0.4471 & 0.0000 & 0.0014 & 0.1089 & & & & & \\
\hline $\begin{array}{l}\text { GROW } \\
\text { TH }\end{array}$ & 0.0297 & -0.0098 & -0.0498 & 0.0020 & 0.0540 & $0.1316^{*}$ & 1.0000 & & & \\
\hline & 0.5809 & 0.8559 & 0.3545 & 0.9702 & 0.3151 & 0.0140 & & & & \\
\hline $\begin{array}{l}\text { EISSU } \\
\text { E }\end{array}$ & $-0.0924^{*}$ & $0.1016^{*}$ & -0.0563 & -0.0612 & $0.2170^{*}$ & 0.0044 & $0.2613^{*}$ & 1.0000 & & \\
\hline & 0.0853 & 0.0582 & 0.2951 & 0.2552 & 0.0000 & 0.9343 & 0.0000 & & & \\
\hline $\begin{array}{l}\text { DISSU } \\
\text { E }\end{array}$ & $-0.1364^{*}$ & 0.0705 & 0.0184 & 0.0570 & $0.1809^{*}$ & $0.1622^{*}$ & $0.1911^{*}$ & $0.3155^{*}$ & 1.0000 & \\
\hline & 0.0109 & 0.1896 & 0.7323 & 0.2890 & 0.0007 & 0.0024 & 0.0003 & 0.0000 & & \\
\hline SIZE & $0.1162^{*}$ & $0.1991^{*}$ & $-0.2662^{*}$ & $0.4128^{*}$ & $-0.2852^{*}$ & $0.4180^{*}$ & $0.1259^{*}$ & 0.0835 & $0.1536^{*}$ & 1.0000 \\
\hline & 0.0302 & 0.0002 & 0.0000 & 0.0000 & 0.0000 & 0.0000 & 0.0188 & 0.1200 & 0.0041 & \\
\hline
\end{tabular}

$*$ represents the level of significance $<=10 \%$ in two-tailed tests.

\subsection{Earnings smoothing}

Table 3, Panel A presents the regression results in relation to the smoothing of earnings pre- and post-adoption of the new accounting regime. The first finding (Equation 2) relating to the variability of the change in net income scaled by total assets $(\Delta \mathrm{NI})$ indicates that firms in the post-adoption period exhibit a significantly higher variability of change in net income, $\Delta \mathrm{NI}^{\#}(0.0797$ versus 0.0505 in the preadoption period). This difference of residual variances of 0.0292 represents $58 \%$ of the total variance of the change in net income and it is significant at the 1 percent level.

The second earnings smoothing finding (Equation 3) indicates that the ratio of the variance of change in net income, $\Delta \mathrm{NI}^{\#}$, to the variance of change in cash flow, $\Delta \mathrm{CF}^{\#}$, is higher for firms in the postadoption period than for firms in the pre-adoption period (3.2735 and 1.5961, respectively) and that the difference is significant at the 1 percent level.

The third earnings smoothing finding (Equation 8) indicates that the correlation between accruals, $A C C^{\#}$, and cash flow, $C F^{\#}$, for firms in the post-adoption period $(-0.7972)$ is less negative than for firms in the pre-adoption period (-0.8404). Although the difference is not significant, the finding suggests that earnings smoothing may have reduced following the adoption of the new corporate accounting regime. 
Thus, the results overall in Panel A of Table 3 are consistent with our expectation that the adoption of the new corporate accounting regime in Vietnam has led to a significant decline in earnings smoothing. As we have noted, findings with regard to mandatory adoption of the rules have not always been one way. Our findings here are consistent with Chua et al. (2012) who find that mandatory adoption of IFRS has generally improved accounting quality in regard to smoothing behavior in Australia.

\subsection{Managing earnings toward a positive target}

Table 3, Panel B presents the regression result for the management of earnings towards targets in relation to the corporate accounting regime. As antipated by our hypothesis, we find a significantly negative association between the management of earnings toward small positive amounts (SPOS) and the adoption of the new corporate accounting regime (POST) ( $\mathrm{p}$ value $=0.008$ ) indicating that firms engage in managing earnings towards a target to a lesser extent following the adoption. Our findings here are consistent with Chen et al. (2010), who compared the accounting quality of publicly listed companies in 15 member states of the European Union before and after the full adoption of IFRS in 2005 and find less of management of earnings toward a target following IFRS adoption.

Table 3

Earnings Management Analysis

Panel A. Earnings smoothing metrics

\begin{tabular}{|c|l|c|c|c|c|c|c|}
\hline & Prediction & $\begin{array}{c}\text { Pre-adoption } \\
(\mathbf{N}=174)\end{array}$ & $\begin{array}{c}\text { Post- } \\
\text { adoption (N } \\
\mathbf{1} \text { 174) }\end{array}$ & Difference & \%Difference & Sig. \\
\hline $\begin{array}{c}\text { Eq. } \\
(2)\end{array}$ & Variability of $\Delta \mathrm{NI}^{\#}$ & + & 0.0505 & 0.0797 & 0.0292 & $58 \%$ & $* * *$ \\
\hline $\begin{array}{c}\text { Eq. } \\
(3)\end{array}$ & $\begin{array}{l}\text { Variability of } \\
\mathrm{NNI} / \Delta \mathrm{CF}\end{array}$ & + & 1.5961 & 3.2735 & 1.6773 & $105 \%$ & $* * *$ \\
\hline $\begin{array}{l}\text { Eq. } \\
(8)\end{array}$ & $\begin{array}{l}\text { Correlation } \\
\text { between ACC\# } \\
\text { and CF\# }\end{array}$ & + & -0.8404 & -0.7972 & 0.0432 & $5.14 \%$ & No \\
\hline
\end{tabular}

$\triangle N I^{\#}, \triangle C F^{\#}, C F^{\#}$, and $A C C^{\#}$ are defined as the residuals from the regressions of $\triangle N I, \triangle C F, C F$, and $A C C$, respectively, based on Equations from (1) to (3). Postadoption includes all observations after a firm adopts the new corporate accounting regime (as of January 1, 2015).

*, **, *** Represent significant difference between the pre-adoption and the post-adoption periods at the 10\%, 5\%, and 1\% levels, respectively

Panel B. Managing earnings toward a positive target

\begin{tabular}{|l|c|c|c|c|c|c|c|c|c|c|}
\hline & $\boldsymbol{\alpha} \mathbf{0}$ & POST & $\mathbf{C F}$ & $\mathbf{B I G} 4$ & TURN & LEV & GROWTH & EISSUE & DISSUE & SIZE \\
\hline Coefficient & 0.0374 & -0.0791 & -0.1029 & -0.0098 & -0.0803 & 0.2505 & 0.0165 & -0.0085 & -0.0790 & 0.0073 \\
\hline p-value & 0.919 & 0.008 & 0.171 & 0.764 & 0.000 & 0.012 & 0.643 & 0.915 & 0.003 & 0.816 \\
\hline Sig. & & $* * *$ & & & $* * *$ & $* *$ & & & $* * *$ & \\
\hline
\end{tabular}

$\mathrm{R}^{2}=0.1311, \mathrm{p}$-value of 0.0000 and $\mathrm{N}=348$.

Statistical significance is indicated by $* * *, * *$, and $*$ for $1 \%, 5 \%$, and $10 \%$.

For the control variables, we observe that the relationship between financial leverage (LEV) and SPOS is significantly positive (at 5\% level), while the relationships between asset turnover rate (TURN) and SPOS and between debt issuing (DISSUE) and SPOS are negative (at 1\% level). 
Overall, the findings provide support for the conclusion that the mandatory adoption of the new accounting regime has generally improved accounting quality in Vietnam.

\section{CONCLUSION}

This paper examines the impact of the new corporate accounting regime, which brings Vietnamese accounting standards closer to IFRS, on the reporting behavior of firms in Vietnam. Specifically, the paper compares reporting behavior in relation to the earnings management before and after mandatory adoption of the new corporate accounting regime as of January 1, 2015.

The result indicates that subsequent to the implementation of the new corporate accounting regime, Vietnamese-listed firms exhibit less earnings management, suggesting an improvement to accounting quality. Thus, we are able to support the expectation of the Ministry of Finance of Vietnam, namely that adoption of the new corporate accounting regime should enhance the overall quality of the financial reporting system.

For developed countries, notwithstanding a good deal of reporting, a consensus as to the implications of the new rules has yet to emerge. Although much fewer studies have been conducted for emerging economies, it is interesting to observe that findings reported for countries as diverse as Brazil and Pakistan (above) are in accord with our findings for Vietnamese firms,

The study is not free from limitations. First, although the regression model has incorporated standard variables to control for the effect of factors which are exogenous in respect to the accounting regime, it may be that other incentives to manage earnings have not been controlled for. Second, this study only uses four constructs to proxy two perspectives of earnings management to identify earnings smoothing and management of earnings towards a positive target. However, the application of earnings management is subtle and not directly observable. Thus, additional proxies for such application, such as discretionary accruals, earnings persistence and accruals quality, might be usefully incorporated in future studies. Third, the single emerging country of this study may not allow us to generalize our findings to other countries.

\section{REFERENCES}

Ahmed, A. S., Neel, M., \& Wang, D. (2013). Does Mandatory Adoption of IFRS Improve Accounting Quality? Preliminary Evidence. Contemporary Accounting Research, 30(4), 1344-1372. doi: doi:10.1111/j.19113846.2012.01193.x

Ashbaugh, H., \& Pincus, M. (2001). Domestic Accounting Standards, International Accounting Standards, and the Predictability of Earnings. Journal of accounting research, 39(3), 417-434. doi: doi:10.1111/1475-679X.00020

Bach, L. T., \& Hang, N. T. (2016). Accounting information quality in emerging markets: Conservatism in financial reporting of Vietnamese firms in the context of international economic integration. International Journal of Economics and Financial Issues, 6(6S), 88-93.

Baig, M., \& AliKhan, S. (2016). Impact of IFRS on Earnings Management: Comparison of Pre-Post IFRS Era in Pakistan, Procedia - Social Behavioral Science, 230, 343-350.

Barth, M. E., Landsman, W. R., \& Lang, M. H. (2008). International accounting standards and accounting quality. Journal of accounting research, 46(3), 467-498.

Capkun, V., Collins, D. \& Jeanjean, T. (2016). The effect of IAS/IFRS adoption on earnings management (smoothing): A closer look at competing explanations. Journal of Accounting and Public Policy, 35(4), 352-394.

Chen, H., Tang, Q., Jiang, Y., \& Lin, Z. (2010). The role of international financial reporting standards in accounting quality: Evidence from the European Union. Journal of international financial management \& accounting, 21(3), 220278. 
Christensen, H. B., Lee, E., Walker, M., \& Zeng, C. (2015). Incentives or Standards: What Determines Accounting Quality Changes around IFRS Adoption?. European Accounting Review, 24(1), 31-61. doi: 10.1080/09638180.2015.1009144

Callao, S. \& Jarne, J. I (2010), Have IFRS Affected Earnings Management in the European Union? Accounting in Europe, 7(2), 159-189.

Chua, Y. L., Cheong, C. S., \& Gould, G. (2012). The impact of mandatory IFRS adoption on accounting quality: Evidence from Australia. Journal of International Accounting Research, 11(1), 119-146.

Doukakis, L. C. (2014). The effect of mandatory IFRS adoption on real and accrual-based earnings management activities. Journal of Accounting and Public Policy, 33(6), 551-572. doi: https://doi.org/10.1016/j.jaccpubpol.2014.08.006

Jeanjean, T., \& Stolowy, H. (2008). Do accounting standards matter? An exploratory analysis of earnings management before and after IFRS adoption. Journal of Accounting and Public Policy, 27(6), 480-494. doi: https://doi.org/10.1016/j.jaccpubpol.2008.09.008

Huynh, T., Doan, D., \& Gong, G. (2012). Vietnamese accounting system reform-Review and prospect. Australian Journal of Basic and Applied Sciences, 6(9), 629-651.

Malofeeva, T. N. (2018). The Impact of IFRS Adoption on Earnings Management in Russia. European Research Studies Journal, European Research Studies Journal, 2, 147-164.

Paananen, M., \& Lin, H. (2009). The Development of Accounting Quality of IAS and IFRS over Time: The Case of Germany. Journal of International Accounting Research, 8(1), 31-55. doi: 10.2308/jiar.2009.8.1.31

Pelucio-Grecco, M. C., Geron, C. M. S., Grecco, G. B., \& Lima, J. P. C. (2014). The effect of IFRS on earnings management in Brazilian non-financial public companies, Emerging Markets Review, 21. 42-66.

Phan, K. C., \& Zhou, J. (2014). Market efficiency in emerging stock markets: A case study of the Vietnamese stock market. IOSR Journal of Business and Management, 16(4), 61-73.

Prior, D., Surroca, J., \& Tribó, J. A. (2008). Are socially responsible managers really ethical?: exploring the relationship between earnings management and corporate social responsibility. Corporate governance, 16(3), 160177. doi: 10.1111/j.1467-8683.2008.00678.x

Truong, D. L., Ger, L., \& Robert, L. (2008). Stock-market efficiency in thin-trading markets: the case of the Vietnamese stock market. Applied Economics, 42(27), 3519-3532. doi: 10.1080/00036840802167350

Wali, S., \& Boujelbene, Y. (2017). IFRS Mandatory Adoption Effect on Information Asymmetry: Immediate or Delayed? Australasian Accounting Business \& Finance Journal, 11(1), 55. 